\title{
Meat quality of lambs supplemented with intramuscular vitamin $\mathbf{E}^{1}$
}

\author{
Aline A. Morgado ${ }^{2 *}$, Giovanna R. Nunes², Beatriz R. Villas Bôas², \\ Paola B.J. Carvalho², Paulo H.M. Rodrigues ${ }^{3}$, Ivanete Susin $^{4}$, \\ Maria Claudia A. Sucupira ${ }^{2}$ and Angélica S.C. Pereira ${ }^{3}$
}

\begin{abstract}
Morgado A.A., Nunes G.R., Villas Bôas B.R., Carvalho P.B.J., Rodrigues P.H.M., Susin I., Sucupira M.C.A. \& Pereira A.S.C. 2018. Meat quality of lambs supplemented with intramuscular vitamin E. Pesquisa Veterinária Brasileira 38(4):679-684. Departamento de Clínica Médica, Faculdade de Medicina Veterinária e Zootecnia, Universidade de São Paulo, Avenida Prof. Dr. Orlando Marques de Paiva 87, São Paulo, SP 05508-270, Brazil. E-mail: msucupir@usp.br

This study evaluated the effects of intramuscular alpha-tocopherol (vitamin E) supplementation on meat quality characteristics of Santa Inês and Dorper crossbreed lambs. All animals were feed with a high concentrated diet in feedlot. Eight days before slaughter, the animals were distributed into four blocks according to weight gain. At the seventh and fourth days before slaughter, they were intramuscularly treated with 0, 10 or 20 IU of DL-alpha-tocopherol per kg of metabolic body weight. At slaughter they had 138 days of age and $43.6 \mathrm{~kg}$ of live weight, in average. Carcasses were stored for 24 hours under refrigeration at $2^{\circ} \mathrm{C}$. Longissimus thoracis muscle pH (pH24h) and color (lightness, yellowness and redness) were analyzed and its samples were collected for evaluation of shear force (SF), cooking loss (WLC), fatty acid composition (FA) and thiobarbituric acid reactive substances after one (TBARS1m) and after five months (TBARS5m) of freezing. Linearity deviation effect was observed for lightness $\left(\mathrm{L}^{*} ; \mathrm{P}=0.0042\right.$ ) and yellowness ( $\left.\mathrm{b}^{*} ; \mathrm{P}=0.0082\right)$. Intramuscular administration of 10 or $20 \mathrm{IU}$ of alpha-tocopherol/kg of metabolic weight did not influence the conservation of fatty acid in the carcasses, but benefit $\mathrm{L}^{*}$ and $\mathrm{b}^{*}$ values.
\end{abstract}

INDEX TERMS: Meat quality, lambs, vitamin E, antioxidant, parenteral supplementation, sheep, fatty acid composition.

RESUMO.- [Qualidade da carne de cordeiros suplementados com vitamina $E$ por via intramuscular.] 0 estudo avaliou os efeitos da suplementação pela via intramuscular de alfa-tocoferol (vitamina E) na qualidade da carne de cordeiros mestiços Santa Inês e Dorper. Os animais foram mantidos em confinamento, sendo alimentados com dieta contendo alto teor de concentrado energético. Oito dias antes do abate os cordeiros foram distribuídos em quatro blocos, de acordo com

\footnotetext{
${ }^{1}$ Received on March 13, 2017.

Accepted for publication on April 7, 2017.

${ }^{2}$ Departamento de Clínica Médica, Faculdade de Medicina Veterinária e Zootecnia (FMVZ), Universidade de São Paulo (USP), Avenida Prof. Orlando Marques Paiva 87, Cidade Universitária, São Paulo, SP 05508-900, Brazil. *Corresponding author: msucupir@usp.br

${ }^{3}$ Departamento de Nutrição e Produção Animal, Faculdade de Medicina Veterinária e Zootecnia (FMVZ), Universidade de São Paulo (USP), Av. Duque de Caxias Norte 225, Pirassununga, SP 13635-900, Brazil.

${ }^{4}$ Departamento de Zootecnia, Escola Superior de Agricultura Luis de Queiroz (ESALQ), Universidade de São Paulo (USP), Av. Pádua Dias 11, Piracicaba, SP 13418-900, Brazil.
}

seu ganho de peso. No sétimo e quarto dias antes do abate eles foram tratados por via intramuscular com 0,10 ou $20 \mathrm{UI}$ de DL-alfa-tocoferol por kg de peso metabólico. No momento do abate os animais tinham, em média, 138 dias de idade e $43,6 \mathrm{~kg}$ de peso vivo. As carcaças foram armazenadas a $2^{\circ} \mathrm{C}$ por 24 horas. Foram determinados $\mathrm{pH}$ (pH24h) e cor (luminosidade, teor de vermelho e teor de amarelo) do músculo Longissimus thoracis, bem como força de cisalhamento, perda por cocção, composição dos ácidos graxos e quantidade de substâncias reativas ao ácido tiobarbitúrico após um e cinco meses de congelamento. Observou-se efeito de desvio da linearidade para luminosidade ( $\mathrm{L}^{*} ; \mathrm{P}=0.0042$ ) e para o croma amarelo (b*; $\mathrm{P}=0.0082$ ). A administração intramuscular de 10 e 20 UI de alfa-tocoferol $/ \mathrm{kg}$ de peso metabólico não influenciou a conservação de ácidos graxos das carcaças, mas melhorou os valores de L* e b*.

TERMOS DE INDEXAÇ̃̃O: Qualidade da carne, cordeiros, vitamina E, antioxidante, suplementação parenteral, ovinos, composição de ácidos graxos. 


\section{INTRODUCTION}

Meat cuts are generally purchased by consumers after their exposure in shops during varied periods of time (Dufrasne et al. 2000). A survey pointed color as the most important characteristic to consumers (Muchenje et al. 2009) and it is well stablished that loss of meat color is closely related to oxidation of their pigments and lipids (Sherbeck et al. 1995).

Besides that, consumers are increasingly motivated to eat healthy meat, rich in unsaturated fatty acids, omega-3 and omega- 6 fatty acids and conjugated linoleic acid (CLA) (Maia et al. 2012). It is known that the meat of ruminant animals has more concentration of CLA than non-ruminant meats and, among ruminants, ovine meat has the greater quantity of CLA (Schmid et al. 2006).

Lipid oxidation is, though, one of the major causes of meat deterioration during its storage. Besides color alteration, it is also responsible for changes in smell, taste and nutritional value (Morrissey et al. 1994, Atay et al. 2009). The stability of meat cut is influenced by the level and kinds of its fatty acid composition and antioxidant status (Ponnampalam et al. 2010). Changes in flavor are directly related to the rancidity, mainly when there is high unsaturated fatty acid content (Macit et al. 2003b). Offering products with pleasant color and flavor with greater safety and lower costs is a challenge to the meat industry.

To extend the shelf life of meat, vacuum or modified atmosphere packaging has been frequently used (Mohamed et al. 2008). Moreover, it has also been increasing the use of natural antioxidants, like vitamin E, which is commonly used as a supplement in feed for farm animals (Morrissey et al. 1994) because it improves the stability of meat pigments and lipids (Lauzurica et al. 2005) improving meat color and extending shelf-life of meat products (Mohamed et al. 2008).

Vitamin $\mathrm{E}$ is the main lipid-soluble biological antioxidant and the alpha-tocopherol is its most important biologically active form (Lauzurica et al. 2005). The dietary supplementation with vitamin E increases the amount of alpha-tocopherol deposited on muscle and fat, which neutralizes free radicals before lipid oxidation occurs in unsaturated fatty acids of cell membranes (Liu et al. 1995). Several studies showed benefits of dietetic vitamin $\mathrm{E}$ administration on the meat quality of swine (Cheah et al. 1995), cattle (Dufrasne et al. 2000) and sheep (Guidera et al. 1997, Macit et al. 2003a, 2003b, Lauzurica et al. 2005, Atay et al. 2009, Kasapidou et al. 2012). However, there is little information about its parenteral supplementation (Maiorano et al. 2005), which encouraged this study about the effects of intramuscular vitamin E administration on meat quality characteristics of Santa Inês and Dorper crossbred lambs.

\section{MATERIALS AND METHODS}

This study was approved by the "Ethic Committee in the use of animals" of School of Veterinary Medicine and Animal Science of University of São Paulo (protocol number 2422/2011).

Animals and management. Twenty-four weaned Santa Inês and Dorper crossbred male, healthy and non-castrated lambs were used. At the slaughter, animals had 138 days of age and $43.6 \mathrm{~kg}$ of live weight, in average. The lambs were maintained in feedlot, in collective pens, during 75 days. After the first 15 days adaptation period, lambs were fed a diet with $80 \%$ of commercial concentrate (Tech Ovin
Pasture Socil ${ }^{\circledR}$ ) and 20\% of chopped Tifton 85 hay (Cynodon spp.), ensuring $10 \%$ of leftovers. The hay showed $89.42 \%$ of dry matter (DM), $11.58 \%$ of crude protein and $82.74 \%$ of neutral detergent fiber. The commercial concentrate had $90.38 \%$ of DM, $17.17 \%$ of crude protein, $10.79 \%$ of crude fiber, $2.49 \%$ of ether extract and $2.49 \mathrm{kcal}$ $\mathrm{x} \mathrm{g}^{-1}$ of gross energy. According to the manufacturer, the vitamin $\mathrm{E}$ quantity in the commercial concentrate was the minimum required (8.75 $\left.\mathrm{UI} \mathrm{x} \mathrm{kg}^{-1}\right)$. The water was offered ad libitum.

A randomized block with repetition was used, in which eight days before slaughter animals were distributed according to the weight gain into four blocks with six animals each, two animals per treatment into each block, totalizing eight animals per treatment. On the seventh and fourth day before slaughter, lambs were treated intramuscularly between semimembranosus and semitendinosus muscles with saline solution (control group), 10IU or 20IU of DL-alpha-tocopherol acetate (Monovin $\mathrm{E}^{\circledR}$, Bravet) per metabolic weight (body weight ${ }^{0,75}$ ). The first application was made on the right hindlimb and the second on the left one.

Carcass and meat traits. All lambs were transported by four hours of road transport by a highway with great pavement conditions. The slaughter was carried out in the slaughterhouse school at University of Sao Paulo, Brazil, in accordance with the Brazilian Federal Inspection Service procedures.

After stored for 24 hours in a cold room at $0-2^{\circ} \mathrm{C}, 2.5 \mathrm{~cm}$ thick samples were collected from the Longissimus thoracis (LT), between the 12th and 13th ribs of each left half carcass.

The $\mathrm{pH}$ (pH24h) was measured by portable pHmeter (HI 99163, Hanna) in the right half of the chilled carcasses, on a cross section of the LT muscle on the 12th rib area.

During boning, color of LT muscle sampled between 12th and 13th ribs was determined 24 hours after slaughter by portable colorimeter (Minolta Color Reader CR-10) using D65 light source, $10^{\circ}$ viewing angle and $30 \mathrm{~mm}$ opening of the measuring cell. CIELab system scale was used to determine $\mathrm{L}^{*}$ (luminosity), a* (red color) and $b^{*}$ (yellow color) values. Furthermore, samples of LT muscle were collected; vacuum packaged and frozen at $-20^{\circ} \mathrm{C}$ for analysis of cooking loss, tenderness and lipid oxidation.

Cooking loss (WLC) were determined by weight differences before and after baking, expressed in percentage [WLC $=(\mathrm{iW}-\mathrm{fW}) / \mathrm{iW}]$.

Tenderness was determined according to Wheeler et al. (1995). Samples were defrosted to reach $2^{\circ} \mathrm{C}$ to $5^{\circ} \mathrm{C}$ temperature, and then placed on identified grids where they were weighed and roasted until reaching inner temperature of $71^{\circ} \mathrm{C}$, controlled by a thermocouple connected to a thermometer. After that, samples were cooled to room temperature, re-weighed and placed in a refrigerator for 24 hours. Six cylinders of meat were extracted from each sample, $1 / 2$ inch from the sample core in the longitudinal muscle fibers using a dielectric handheld device.

Meat tenderness was determined by the Salter Warner-Bratzler Shear Mechanical Force machine with $25 \mathrm{~kg}$ capacity and sectioning speed of $20 \mathrm{~cm} /$ minute. The value of each sample was given by the arithmetic mean of these cylinders, expressed in $\mathrm{kg}$.

Lipid oxidation products were measured according to Buege and Aust (1978) methodology and expressed as thiobarbituric acid reactive substances in frozen meat samples at $-20^{\circ} \mathrm{C}$ for one (TBARS1m) and five months (TBARS5m).

Meat fatty acids profile was determined using the extraction method standardized by Bligh and Dyer (1959), in which 125g of minced meat were homogenized with $125 \mathrm{~mL}$ chloroform and $200 \mathrm{~mL}$ methanol (monophasic system). The solution was re-homogenized with $125 \mathrm{~mL}$ of chloroform and $125 \mathrm{~mL}$ of $0.88 \% \mathrm{NaCl}$ solution was 
added. The final emulsion was centrifuged at 13,000G for $5 \mathrm{~min}$ at $25^{\circ} \mathrm{C}$. After filtration under suction, the final system was separated into two layers; the upper phase was removed and the lower phase (chloroform) was evaporated under nitrogen (Iverson et al. 2001). Samples were esterified using direct esterification technique (Shirai et al. 2005) and its composition was determined by gas chromatography (Agilent 7890, Agilent Technologies Inc., Santa Clara, USA). A fused silica capillary column (J \& W DB-23 Agilent 122-236; $60 \mathrm{~m} \times 250 \mathrm{~mm}$ of internal diameter) was used for sample injection. Helium was used as the gas flower. The column temperature program started at $80^{\circ} \mathrm{C}, 5^{\circ} \mathrm{C} / \mathrm{min}$ heating rate up to $175^{\circ} \mathrm{C}$, followed by of $3^{\circ} \mathrm{C} / \mathrm{min}$ heating rate up to $230^{\circ} \mathrm{C}$, maintaining $230^{\circ} \mathrm{C}$ for 5 minutes. Temperatures of the injector and the detector (FID) were $250^{\circ} \mathrm{C}$ and $280^{\circ} \mathrm{C}$, respectively. Fatty acids were identified by comparison of retention time of methyl esters of the samples with fatty acids standard (Sigma Chemical Co.: 4-7801, U-47085, U-49453, U-47885).

Fatty acids were quantified by normalizing the area under the curve of methyl esters. Fatty acids content were expressed in percentage of total fatty acid methyl ester quantified.

Data was analyzed by SAS program (Version 9.3, 2010) by MIXED proceedings. The normality of the distribution of residuals was tested by Shapiro-Wilk test. Outliers were looked for by the UNIVARIATE proceeding. The effect of vitamin E dose was evaluated by polynomial regression, using orthogonal polynomials. Treatment effects were decomposed on linear effect and linearity deviation effect. The significance level was $5 \%$ for all tests.

\section{RESULTS}

Table 1 shows the means, standard error of mean and probabilities of the meat quality characteristics of sheep treated with 0,10 or 20 IU of intramuscular vitamin E.

Vitamin E treatment showed linearity deviation effect for $\mathrm{L}^{*}$ and $\mathrm{b}^{*}$ chromaticity and lambs treated with $10 \mathrm{IU}$ of DL-alpha-tocopherol acetate showed the highest average. The regression equations for those variables were, respectively, $\mathrm{Y}=27.12+0.6473 \mathrm{x}-0.0309 \mathrm{x}^{2}\left(\mathrm{R}^{2}=0.33\right)$ and $\mathrm{Y}=10.15+0.2721 \mathrm{x}$ - $0.0125 \mathrm{x}^{2}\left(\mathrm{R}^{2}=0.29\right)$, in which " $\mathrm{Y}$ " is the chromaticity and " $\mathrm{x}$ " is the level of vitamin $\mathrm{E}$.
Table 2 shows the means, standard error of mean and probabilities of the fatty acids composition of lambs' meat treated with 0,10 or 20 IU of intramuscular vitamin E. There were no differences between treatments for fatty acid composition.

\section{DISCUSSION}

The final $\mathrm{pH}$ ( $\mathrm{pH}$ of 24 to 48 hours post mortem) is an important indicator of meat quality (Hoffman et al. 2003). When it is high, it favors the development of dark, firm and dry (DFD) meat. DFD meat is unattractive to consumers due to its dark color, parched appearance and beyond that it is more susceptible to bacterial decay (De la Fuente et al. 2010).

The maximum final $\mathrm{pH}$ acceptable in sensorial panel is 5.8 for ovine meat (Devine et al. 1993). According to it both treated and control groups showed suitable $\mathrm{pH}$, but there was no effect of the vitamin E administration. It was also related by Macit et al. (2003a), Lauzurica et al. (2005) and Kasapidou et al. (2012) after dietetic supplementation and by Maiorano et al. (2005) after intramuscular supplementation for five weeks with different doses of vitamin $\mathrm{E}$.

Tenderness can be defined as the easiness which meat is chewed (Maturano 2003). It can be determined subjectively, using a sensory panel, or objectively, using a device to measure the force needed to shear a meat sample (Alves et al. 2005), as in this case. The greater the shear force is, the smaller the smoothness provided by cut meat (Muchenje et al. 2009). The softness mainly varies due to changes in the structure of the myofibrillar proteins (actin and myosin) in the period between slaughter and meat consumption (Muir et al. 2000).

The vitamin E protocol used in this study was not efficient to affect tenderness. Lambs treated with $45 \mathrm{mg}$ of vitamin $\mathrm{E}$ in their diet for 75 days also did not show different tenderness of the control group (Macit et al. 2003b). Maybe a longer treatment with vitamin $\mathrm{E}$ is required to improve tenderness. Although the values obtained in this study have been numerically higher than those found by Macit et al. (2003b), all of them were less than $4.50 \mathrm{~kg}$, the limit amount for consumers classify beef as soft and acceptable (Knapp et al. 1989).

Table 1. Means, standard error of mean and probabilities of $\mathrm{pH}$ meat values after 24 hours of slaughter, shear force, cooking loss, color and lipid oxidation after one and 5 freezing months in lamb meat of animals treated intramuscularly with 0,10 or $20 \mathrm{IU}$ of vitamin $\mathrm{E} / \mathrm{kg}$ of metabolic weight on the seventh and fourth day prior slaughter

\begin{tabular}{|c|c|c|c|c|c|c|}
\hline \multirow{2}{*}{ Item } & \multicolumn{3}{|c|}{ Treatments } & \multirow{2}{*}{ SEM $^{\mathrm{a}}$} & \multicolumn{2}{|c|}{ Effect $^{\mathrm{b}}$} \\
\hline & Control & $10 \mathrm{IU}$ & $20 \mathrm{IU}$ & & $\mathrm{L}$ & LD \\
\hline pH $24 h$ & 5.67 & 5.61 & 5.71 & 0.02 & $\mathrm{NS}^{\mathrm{c}}$ & NS \\
\hline $\begin{array}{l}\text { Subcutaneous fat thickness } \\
(\mathrm{cm})\end{array}$ & 0.24 & 0.29 & 0.23 & 0.02 & NS & NS \\
\hline $\mathrm{SF}^{\mathrm{d}}, \mathrm{kgf}$ & 4.10 & 4.43 & 4.30 & 0.17 & NS & NS \\
\hline Cooking loss, $\%$ & 20.17 & 20.50 & 19.89 & 0.52 & NS & NS \\
\hline $\mathrm{L}^{*}$ & 27.12 & 30.50 & 27.69 & 0.54 & NS & 0.0042 \\
\hline$a^{*}$ & 16.11 & 14.98 & 16.21 & 0.39 & NS & NS \\
\hline$b^{*}$ & 10.14 & 11.61 & 10.57 & 0.24 & NS & 0.0082 \\
\hline TBARS1m, mgMDA ${ }^{\mathrm{e}}$ meat kg-1 & 0.92 & 1.01 & 1.14 & 0.08 & NS & NS \\
\hline TBARS5m, mgMDA meat kg-1 & 0.85 & 0.79 & 0.96 & 0.06 & NS & NS \\
\hline
\end{tabular}

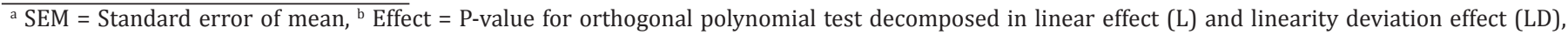

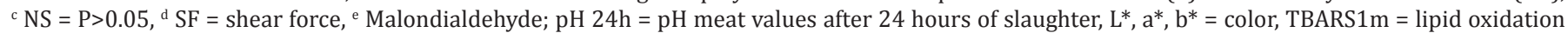
after one freezing months, TBARS5m = lipid oxidation after 5 freezing months. 
Table 2. Means, standard error of mean and probabilities of fatty acid profile, expressed as a percentage of total fatty acid methyl esters, in Longissimus thoracis muscle from lambs treated intramuscularly with 0, 10 or $20 \mathrm{IU}$ of vitamin E/ kg of metabolic weight on the seventh and fourth day prior slaughter

\begin{tabular}{|c|c|c|c|c|c|c|}
\hline \multirow{2}{*}{ Fatty acid } & \multicolumn{3}{|c|}{ Treatments } & \multirow{2}{*}{ SEM $^{\mathrm{a}}$} & \multicolumn{2}{|c|}{ Effect $^{\text {b }}$} \\
\hline & 0 & 10 & 20 & & $\mathrm{~L}$ & LD \\
\hline C6:0 & 0.144 & 0.089 & 0.114 & 0.012 & $\mathrm{NS}^{\mathrm{c}}$ & NS \\
\hline C8:0 & 0.152 & 0.143 & 0.151 & 0.01 & NS & NS \\
\hline C11:0 & 0.173 & 0.019 & 0 & 0.196 & NS & NS \\
\hline C12:0 & 0.318 & 0.313 & 0.299 & 0.054 & NS & NS \\
\hline C15:0 & 0.273 & 0.3 & 0.29 & 0.008 & NS & NS \\
\hline C15:1 & 1.026 & 0.368 & 1.033 & 0.222 & NS & NS \\
\hline C16:0 & 23.905 & 23.433 & 22.846 & 0.265 & NS & NS \\
\hline C16:1 & 0.487 & 0.41 & 0.436 & 0.027 & NS & NS \\
\hline C16:1 n9 & 1.413 & 1.166 & 1.299 & 0.091 & NS & NS \\
\hline C18:2n6c & 7.235 & 6.271 & 7.171 & 0.383 & NS & NS \\
\hline $\mathrm{C} 18: 2 \mathrm{n} 6 \mathrm{t}$ & 0.191 & 0.162 & 0.168 & 0.012 & NS & NS \\
\hline C18:3 n3 & 0.531 & 0.312 & 0.371 & 0.067 & NS & NS \\
\hline C18:3 n6 & 0.101 & 0 & 0.019 & 0.01 & NS & NS \\
\hline C18:4 n3 & 0.441 & 0.414 & 0.412 & 0.022 & NS & NS \\
\hline C20:0 & 0.074 & 0.031 & 0.012 & 0.01 & NS & NS \\
\hline C20:1 n9 & 0.142 & 0.009 & 0.008 & 0.021 & NS & NS \\
\hline C20:2 & 0.453 & 0.393 & 0.474 & 0.029 & NS & NS \\
\hline C20:4 n3 & 0.152 & 0.01 & 0 & 0.02 & NS & NS \\
\hline C20:4 ARA & 2.896 & 2.349 & 2.684 & 0.338 & NS & NS \\
\hline$\sum$ MUFA $^{\mathrm{f}}$ & 36.12 & 37.12 & 37.54 & 0.75 & NS & NS \\
\hline$\sum$ PUFA $^{g}$ & 11.59 & 10.05 & 11.66 & 0.64 & NS & NS \\
\hline UFA/SFA & 1.09 & 1.07 & 1.16 & 0.02 & NS & NS \\
\hline MUFA/SFA & 0.82 & 0.84 & 0.88 & 0.02 & NS & NS \\
\hline PUFA/SFA & 0.27 & 0.23 & 0.28 & 0.02 & NS & NS \\
\hline$\sum n-3$ PUFA $^{\mathrm{h}}$ & 1.27 & 0.93 & 1.04 & 0.10 & NS & NS \\
\hline$\sum n-6$ PUFA $^{\mathrm{i}}$ & 10.04 & 8.78 & 10.14 & 0.57 & NS & NS \\
\hline$n-6 / n-3$ & 8.98 & 9.73 & 9.58 & 0.49 & NS & NS \\
\hline
\end{tabular}

a SEM = Standard error of mean, ${ }^{\mathrm{b}}$ Effect: P-value for orthogonal polynomial test decomposed in linear effect (L) and linearity deviation effect (LD), ${ }^{\mathrm{c}} \mathrm{NS}=\mathrm{P}>0.05,{ }^{\mathrm{d}} \mathrm{SFA}=$ saturated fatty acid (C6:0 + C8:0 + C10:0 + C11:0 + C12:0 + C14:0 + C15:0 + C16:0 + C17:0 + C18:0 + C20:0 + C21:0), ${ }^{\mathrm{e}} \mathrm{UFA}=\mathrm{unsaturated}$ fatty acid (MUFA+PUFA+Omega-3 fatty acids+Omega- 6 fatty acids), ${ }^{\mathrm{f}}$ MUFA $=$ monounsaturated fatty acids $(\mathrm{C} 14: 1 \mathrm{n} 9 \mathrm{c}+\mathrm{C} 15: 1+\mathrm{C} 16: 1 \mathrm{n} 7+\mathrm{C} 16: 1 \mathrm{n} 9 \mathrm{c}+$ C17:1 + C18:1 n9 c + C20:1 n9), g PUFA = polyunsaturated fatty acids (C18:2 n6 t + C18:2 n6 c + C18:3 n3 + C18:3 n6 + C18:4 n3 + C20:2 + C20:4 n3 + C20:4 n6-ARA + C20:5 n3-EPA + C22:2 + C22:5 n3-DPA), ${ }^{\text {h }}$ Omega-3 fatty acids (C18:3 n3 + C18:4 n3 + C20:4 n3 + C20:5 n3-EPA + C22:5 n3-DPA), ${ }^{\mathrm{i}}$ Omega-6 fatty acids (C18:2n6t + C18:2 n6 c + C18:3n6 + C20:4n6-ARA).

Cooking loss is related to the yield of meat when it is cooked. This intramuscular vitamin E supplementation did not affect the WLC values, whose average was $20.19 \%$. Macit et al. (2003b) also found no effect of vitamin E supplementation on
WLC, with average value of $30.70 \%$. The variation of the WLC values in these studies may be the result of using different breeds of sheep, because Costa et al. (2011) concluded that diets with high concentrate levels caused greater fat gain in 
carcasses of crossbred Santa Inês and Dorper lambs than in Santa Ines or mixed breed sheep.

Time course of lipid oxidation is in general evaluated by dosage of thiobarbituric acid reactive substances (TBARS). Its maximum acceptable amount is $1.00 \mathrm{mg}$ of MDA $/ \mathrm{kg}$ of meat (Rippol et al. 2011). Even founding a value that overpasses this limit in 20 IU group, lipid oxidation products in meat cuts frozen for one and five months were not influenced by vitamin E intramuscular supplementation. Lauzurica et al. (2005) and Guidera et al. (1997), however, found lower TBARS values for frozen meat at $-20^{\circ} \mathrm{C}$ for 14 or 28 days and after five months of freezing, respectively, in lambs with dietary vitamin E supplementation than in the control group. Maybe in this experiment the lack of effect with intramuscular supplementation can be related to the dose and number of administration; or maybe the quantity of fat in the carcasses has not been enough to cause problems in rancidity.

Albeit polyunsaturated fatty acids contribute to making healthier meat, they have characteristics that influence negatively meat flavor during its cooking (Monte et al. 2007) and it is know that high levels of PUFA can diminish the shelf-life of the cut, by accelerating lipid oxidation process (Campo et al. 2006). Some authors concluded lipid oxidation in ruminant meat is influenced by the composition of their fatty acids and by the vitamin E concentration in tissues (Arnold et al. 1993, Renerre 2000). According to literature, it was expected that vitamin E could improve the conservation of fatty acid in the carcasses, however it was not observed. Similarly to the other results, it is possible this quantity of vitamin E were not enough to show vitamin E benefits, so more studies should be suggested.

About coloring, contrary to expectations, changes in red color values were not observed and this can be attributed to the amount of vitamin $\mathrm{E}$ administered. $\mathrm{L}^{*}$ and $\mathrm{b}^{*}$, however, showed higher values in animals treated with $10 \mathrm{IU}$ of vitamin $\mathrm{E}$, indicating that their meat were brighter and more yellowish. Vitamin E is characterized to increase brightness because of the retention of water content (Rippol et al. 2011), nevertheless no studies linking vitamin E supplementation to higher values of $b^{*}$ were found. $b^{*}$ indicates the amount of carotenoid pigments of intra and intermuscular fat tissue and it is not directly related to improving the quality of meat (Costa et al. 2011). All samples had b* higher than the limit determined by Bressan et al. (2001), but they were similar to values found by Figueiredo et al. (2015). Different from the observed, Maiorano et al. (2005) found no effect of intramuscular vitamin $\mathrm{E}$ administration on the sheep meat color at 45 minutes and 24 hours post-mortem. When supplemented in the feed, vitamin $\mathrm{E}$ also did not influence the color of lamb (Guidera et al. 1997, Macit et al. 2003a, 2003b, Atay et al. 2009) or bovine (Dufrasne et al. 2000) meat cuts.

\section{CONCLUSION}

Intramuscular supplementation of vitamin $\mathrm{E}$ in doses used in this study apparently did not show enough effects in most aspects of lamb meat quality, but the $10 \mathrm{IU}$ of vitamin E increased brightness and yellowness. It is good to suggest the necessity of other studies related to doses, time of administration and treatment duration for further contributions.

Acknowledgements.- This study was supported by Fundação de Amparo à Pesquisa do Estado de São Paulo (FAPESP), project number 2011/08524-3.

\section{REFERENCES}

Alves D.D., Goes R.H.T.B. \& Mancio A.B. 2005. Maciez da carne bovina. Ciênc. Anim. Bras. 6:135-149.

Arnold R.N., Arp S.C., Scheller K.K., Williams S.N. \& Schaefer D.M. 1993. Tissue equilibration and subcellular distribution of vitamin e relative to myoglobin and lipid oxidation in displayed beef. J. Anim. Sci. 71(1):105-118. http:// dx.doi.org/10.2527/1993.711105x. PMid:8454531.

Atay O., Gökdal Ö., Eren V., Çetiner Ş. \& Yikilmaz H. 2009. Effects of dietary vitamin e supplementation on fattening performance, carcass characteristics and meat quality traits of Karya male lambs. Arch. Tierzucht 52:618-626.

Bligh E.G. \& Dyer W.J. 1959. A rapid method of total lipid extraction and purification. Can. J. Biochem. Physiol. 37(8):911-917. http://dx.doi. org/10.1139/o59-099. PMid:13671378.

Bressan M.C., Prado O.V., Pérez J.R.O., Lemos A.L.S.C. \& Bonagurio S. 2001 Efeito do peso ao abate de cordeiros Santa Inês e Bergamácia sobre as características físico-químicas da carne. Food Sci. Technol. 21(3):293-303. http://dx.doi.org/10.1590/S0101-20612001000300008.

Buege J.A. \& Aust S.D. 1978. Microsomal lipid peroxidation. Methods Enzymol. 52:302-310. http://dx.doi.org/10.1016/S0076-6879(78)52032-6. PMid:672633.

Campo M.M., Nute G.R., Hughes S.I., Enser M., Wood J.D. \& Richardson R.I 2006. Flavour perception of oxidation in beef. Meat Sci. 72(2):303-311. http://dx.doi.org/10.1016/j.meatsci.2005.07.015. PMid:22061558.

Cheah K.S., Cheah A.M. \& Krausgrill D.I. 1995. Effect of dietary supplementation of vitamin E on pig meat quality. Meat Sci. 39(2):255-264. http://dx.doi. org/10.1016/0309-1740(94)P1826-H. PMid:22059831.

Costa R.G., Santos N.M., Sousa W.H., Queiroga C.R., Azevedo P.S. \& Cartaxo F.Q. 2011. Qualidade física e sensorial da carne de cordeiros de três genótipos alimentados com rações formuladas com duas relações volumoso:concentrado. Revta Bras. Zootec. 40(8):1781-1787. http://dx.doi.org/10.1590/S151635982011000800023

De la fuente J., Sánchez M., Pérez C., Lauzurica S., Vieira C., González de Chávarri E. \& Diaz M.T. 2010. Physiological response and carcass and meat quality of suckling lambs in relation to transport time and stocking density during transport by road. Animal 4(2):250-258. PMID: 22443879. http://dx.doi.org/10.1017/S1751731109991108.

Devine C.E., Graafhuis A.E., Muir P.D. \& Chrystall B.B. 1993. The effect of growth rate and ultimate $\mathrm{pH}$ on meat quality of lambs. Meat Sci. 35(1):6377. http://dx.doi.org/10.1016/0309-1740(93)90070-X. PMid:22060837.

Dufrasne I., Marche C., Clinquart A., Hornick J.L., Van Eenaeme C. \& Istasse L. 2000. Effects of dietary vitamin E supplementation on performance and meat characteristics in fattening bulls from the Belgian Blue breed. Livest. Prod. Sci. 65(1/2):197-201. http://dx.doi.org/10.1016/S03016226(99)00173-6.

Figueiredo D.M., Almeida J.C.S., Boari C.A., Paixão M.L., Sena J.A.B., Barbosa J.L., Moreira K.F. \& Ortêncio M.O. 2015. Desempenho, medidas corporais, rendimentos de carcaça e cortes, e qualidade de carne em cordeiros alimentados com resíduos da agroindústria processadora de frutas. Semina, Ciênc. Agrárias 36(1):541-556. http://dx.doi.org/10.5433/16790359.2015v36n1p541.

Guidera J., Kerry J.P., Buckley D.J., Lynch P.B. \& Morrissey P.A. 1997. The effect of dietary vitamin $\mathrm{E}$ supplementation on the quality of fresh and frozen lamb meat. Meat Sci. 45(1):33-43. http://dx.doi.org/10.1016/S03091740(96)00086-1. PMid:22061135.

Hoffman L.C., Muller M., Cloete S.W.P. \& Schmidt D. 2003. Comparison of six crossbred lamb types: sensory, physical and nutritional meat quality characteristics. Meat Sci. 65(4):1265-1274. http://dx.doi.org/10.1016/ S0309-1740(03)00034-2. PMid:22063769.

Iverson S.J., Lang S.L.C. \& Cooper M.H. 2001. Comparison of the Bligh and Dyer and Folch methods for total lipid determination in a broad range 
of marine tissue. Lipids 36(11):1283-1287. http://dx.doi.org/10.1007/ s11745-001-0843-0. PMid:11795862.

Kasapidou E., Wood J.D., Richardson R.I., Sinclair L.A., Wilkinson R.G. \& Enser M. 2012. Effect of vitamin E supplementation and diet on fatty acid composition and on meat colour and lipid oxidation of lamb leg steaks displayed in modified atmosphere packs. Meat Sci. 90(4):908-916. http:// dx.doi.org/10.1016/j.meatsci.2011.11.031. PMid:22177553.

Knapp R.H., Terry C.A., Savell J.W., Cross H.R., Mies W.L. \& Edwards J.W. 1989. Characterization of cattle types to meet specific beef targets. J. Anim. Sci. 67(9):2294-2308. http://dx.doi.org/10.2527/jas1989.6792294x.

Lauzurica S., De la Fuente J., Díaz M.T., Álvarez I., Pérez C. \& Cañeque V. 2005. Effect of dietary supplementation of vitamin $E$ on characteristics of lamb meat packed under modified atmosphere. MeatSci. 70(4):639-646. http:// dx.doi.org/10.1016/j.meatsci.2005.02.013. PMid:22063891.

Liu Q., Lanari M.C. \& Schaefer D.M. 1995. A review of dietary vitamin E supplementation for improvement of beef quality. J. Anim. Sci. 73(10):31313140. http://dx.doi.org/10.2527/1995.73103131x. PMid:8617686.

Macit M., Aksakal V., Emsen E., Aksu M.I., Karaoglu M. \& Esenbuga N. 2003a. Effects of vitamin E supplementation on performance and meat quality traits of Morkaraman male lambs. Meat Sci. 63(1):51-55. http://dx.doi. org/10.1016/S0309-1740(02)00052-9. PMid:22061985.

Macit M., Aksakal V., Emsen E., Esenbuğa N. \& İrfan Aksu M. 2003b. Effects of vitamin E supplementation on fattening performance, non-carcass components and retail cut percentages, and meat quality traits of Awassi lambs. Meat Sci. 64(1):1-6. http://dx.doi.org/10.1016/S03091740(02)00115-8. PMid:22062655.

Maia M.O., Costa F.S., Susin I., Rodrigues G.H., Ferreira E.M., Pires A.V., Gentil R.S. \& Mendes C.Q. 2012. Efeito do genótipo sobre a composição química e o perfil de ácidos graxos da carne de borregas. Revta Bras. Zootec. 41(4):986-992. http://dx.doi.org/10.1590/S1516-35982012000400022.

Maiorano G., Prisciantelli A., Cavone C., Gambacorta M. \& Manchisi A. 2005. Influence of vitamin E treatment starting time on lamb meat quality. Ital. J. Anim. Sci. 4(Suppl. 2):363-365. http://dx.doi.org/10.4081/ijas.2005.2s.363.

Maturano A.M.P. 2003. Estudo do efeito do peso de abate na qualidade da carne de cordeiros da raça Merino Australiano e Ile de France x Merino. Dissertação de Mestrado em Zootecnia, Universidade Federal de Lavras, Lavras. 93p.

Mohamed A., Jamilah B., Abbas K.A. \& Rahman R.A. 2008. A review on lipid oxidation of meat in active and modified atmosphere packaging and usage of some stabilizers. J. Food Agric. Environ. 6:76-81.
Monte A.L.S., Selaive-Villarroel A.B., Garruti D.S., Zapata J.F.F. \& Borges A.S. 2007. Parâmetros físicos e sensoriais de qualidade da carne de cabritos mestiços de diferentes grupos genéticos. Ciênc. Tecnol. Alim. 27(2):233238. http://dx.doi.org/10.1590/S0101-20612007000200004.

Morrissey P.A., Buckley D.J., Sheehy P.J.A. \& Monahan F.J. 1994. Vitamin E and meat quality. Proc. Nutr. Soc. 53(2):289-295. http://dx.doi.org/10.1079/ PNS19940034. PMid:7972143.

Muchenje V., Dzama K., Chimonyo M., Strydom P.E., Hugo A. \& Raats J.G. 2009. Some biochemical aspects pertaining to beef eating quality and consumer health: a review. Food Chem. 112(2):279-289. http://dx.doi.org/10.1016/j. foodchem.2008.05.103.

Muir P.D., Wallace G.J., Dobbie P.M. \& Bown M.D. 2000. A comparison of animal performance and carcass and meat quality characteristics in Hereford, Hereford x Friesian, and Friesian steers grazed together at pasture. N.Z. J. Agric. Res. 43(2):193-205. http://dx.doi.org/10.1080/00288233.200 0.9513421 .

Ponnampalam E.N., Warner R.D., Kitessa S., Mcdonagh M.B., Pethick D.W., Allen D. \& Hopkins D.L.I. 2010. Influence of finishing systems and sampling site on fatty acid composition and retail shelf-life of lamb. Anim. Prod. Sci. 50(8):775-781. http://dx.doi.org/10.1071/AN10025.

Renerre M. 2000. Oxidative processes and myoglobin, p.113-133. In: Deker E.A., Faustman C. \& Lopez-Bote C.J. (Eds), Antioxidants in Muscle Foods: nutritional strategies to improve quality. John Wiley, New York.

Rippol G., Joy M. \& Muñoz F. 2011. Use of dietary vitamin E and selenium (Se) to increase the shelf life of modified atmosphere packaged light lamb meat. MeatSci. 87(1):88-93. http://dx.doi.org/10.1016/j.meatsci.2010.09.008. PMid:20920835.

Schmid A., Collomb M., Sieber R. \& Bee G. 2006. Conjugated linoleic acid in meat and meat products: a review. Meat Sci. 73(1):29-41. http://dx.doi. org/10.1016/j.meatsci.2005.10.010. PMid:22062051.

Sherbeck J.A., Wulf D.M., Morgan J.B., Tatum J.D., Smith G.C. \& Williams S.N. 1995. Dietary supplementation of vitamin $\mathrm{E}$ to feedlot cattle affects beef retail display properties. J. Food Sci. 60(2):250-252. http://dx.doi. org/10.1111/j.1365-2621.1995.tb05648.x.

Shirai N., Suzuki H. \& Wada S. 2005. Direct methylation from mouse plasma and from liver and brain homogenates. Anal. Biochem. 343(1):48-53. http:// dx.doi.org/10.1016/j.ab.2005.04.037. PMid:15964541.

Wheeler T.L., Koohmaraie M. \& Shackelford S.D. 1995. Standardized WarnerBratzler Shear Force Procedures for Meat Tenderness Measurement. Roman L. Hruska U.S. Meat Animal Research Center, Agricultural Research Service, USDA, Clay Center, NE. 